\title{
Response of Tomato Plant to Foliar Application of Calcium and Potassium Nitrate Integrated with Different Phosphorus Rates under Sandy Soil Conditions
}

\author{
A. S. Abd-El-Hamied ${ }^{*}$ and M. A. Abd El-Hady ${ }^{* *}$ \\ *Soil Science Department, Faculty of Agriculture, Damietta University and **Veget. \\ and Flori. Dept., Fac. Agric., Damietta Univ., Egypt
}

\begin{abstract}
$\mathbf{T}$
OMATO is a strategic export vegetable crop in Egypt and the world. So, two field experiments were performed to study the effect of three phosphors rates $(0,14$ and 28 $\mathrm{kg} \mathrm{P}$ fed $\left.^{-1}\right)$; five foliar treatments $(0,0.3$ and $0.6 \%$ of $\mathrm{Ca}$ and $0.5 \%$ and $1 \%$ of $\mathrm{K}$ ) and their interactions on tomato growth and yield.The used experimental design was a split block design with three replicates. Plant height, leaf area, fresh and dry weight $(\mathrm{g})$ of leaves, fruit yield $(\mathrm{Mg}$ fed $^{-1}$ ), fruit diameter, $\mathrm{N}, \mathrm{P}, \mathrm{K}$ and $\mathrm{Ca}$ content (\%) in leaves and uptake in fruits and lycopene content $\left(\mathrm{mg} \mathrm{kg}^{-1}\right)$ were determined. The obtained data reveal that all the used treatments significantly affected the previous parameters. Data also show that phosphorus treatment of 14 $\mathrm{kg} \mathrm{P} \mathrm{fed}{ }^{-1}$ gave the best results of leaf area $\left(\mathrm{cm}^{2}\right)$, fresh weight of tomatoes leaves, potassium content (\%) in leaves, fresh weight of four fruit, fruit diameter and tomatoes yield $\left(\mathrm{Mg} \mathrm{fed}^{-1}\right)$. In addition, foliar application treatments at $0.3 \mathrm{Ca}$ and $0.5 \% \mathrm{~K}$ recorded the highest results of plant height, leaf area $\left(\mathrm{cm}^{2}\right)$, fresh weight of tomato leaves, N, P contents in leaves, weight of four fruits, fruit diameter, tomato yields $\left(\mathrm{Mg} \mathrm{fed}^{-1}\right)$, fruit lycopene content $\left(\mathrm{mg} \mathrm{kg}^{-1}\right), \mathrm{N}$ and $\mathrm{P}$ uptake by fruits. The highest tomato yields $\left(\mathrm{Mg} \mathrm{fed}^{-1}\right)$ values were 18 and $18.06 \mathrm{Mg} \mathrm{fed}^{-1}$ recorded with $14 \mathrm{~kg} \mathrm{P} \mathrm{fed}^{-1}$ and $0.3 \%$ calcium as a foliar application followed by $14 \mathrm{~kg} \mathrm{P}^{-1}$ and $0.5 \%$ potassium which recorded 17.36 and $17.32 \mathrm{Mg} \mathrm{fed}^{-1}$, respectively in both seasons. Generally, it is concluded that the interaction between the treatment of $14 \mathrm{P} \mathrm{fed}^{-1}$ and $0.3 \%$ calcium or $0.5 \%$ potassium as a foliar application enhanced tomato yield and nutrient uptake.
\end{abstract}

Keywords: Tomato , Nutrients uptake, Phosphorus, Lycopene, and Yield.

\section{Introduction}

Tomato (Lycopersicon esculentum) is a strategic export vegetable crop in Egypt and the world.Tomato is widely used in salad as well as for cooking purposes. In Egypt lately, tomatoe plant has been infected by early blight and late blight diseases in wide regions which affected directly tomatoes production. This may be caused by the metrological conditions or increasing nitrogen fertilizers leading to succulent plants which were rapid infected by fungi in addition, no attention to other nutrient especially phosphorus, potassium and calcium.Tomatoes grown in different periods over Egyptian governorates particularly Damietta Governorate where, it isx grown in December and at this time tomatoes showed phosphorus deficiency caused by climatic changes and reduced phosphorus availability especially in alkaline sandy soil. On the other hand, many researchers decided that calcium plays a vital role in the structure of cell walls and cell membranes, fruit growth, and development, as well as general fruit quality (Kadir, 2004). Calcium also can enhance plant resistance to bacterial and viral diseases (Usten et al., 2006). In contrast, $\mathrm{Ca}$ deficiencies cause a decline in the growth of merismatic tissues, reduce leaf size, yields, and causes necrosis of young leaves in extreme cases blossom-end rot (BER). In the case of BER, which can cause severe economic losses (Hao and Papadopoulos, 2003 and Taylor \& Locascio, 2004) especially in alkaline soils suffering from calcium reduction and increasing sodium. On the otherside, potassium involves in many physiological processes, where it impacts the mechanism of stomatal opening and closing by affecting cell water potential and turgor (Rending

*Corresponding author.: E-mail: ahmedsalah@du.edu.eg

DOI : 10.21608/ejss.2017.1645.1126

C)2018 National Information and Documentation Center (NIDOC) 
\& Taylor, 1989 and Very \& Sentenac, 2003), photosynthesis, assimilate transport, enzyme activation, cell turgor maintenance, synthesis of protein and ion homeostasis (Marshner 1995 and Kanai et al., 2011), direct consequences on crop productivity and fruit quality. Additionally, it's also involved in the enrichment of lycopene contents of tomato fruit through synthesis of pigments or carotenoids (Bedari and Hebsur, 2011) and osmotic adjustment. Contrary, under potassium deficient conditions, tomato fruit will be small size, lacking red color especially in alkaline sandy soil. Sandy soils are considered a poor soil from nutrient and people also there is no care about phosphorus fertilization which led to phosphorus deficiency in plants especially at winter seasons. So, phosphorus is considered a key element in several physiological and biochemical processes as well as it achieves a high yield through addition to soil. In General, the balanced supply of nutrients is important to achieve the optimum yield and fruit quality (Akhtar et al., 2010). This study aimed to illustrate the effects of foliar application of calcium and potassium nitrate on tomatoes plant properties grown under different phosphorus rates in sandy soil.

\section{Materials and Methods}

Two field experiments were performed at a private farm, Damietta Governorate , Egypt, during 2013/2014 and 2014/2015 seasons to evaluate the influence of foliar application of potassium and calcium nitrate on tomatoe plant grown in sandy soil under different phosphorus levels. The texture of the used soil was sandy loam and the physical and chemical properties of the used soil are tabulated in Table 1.

TABLE 1. Some physical and chemical properties of the experimental soil

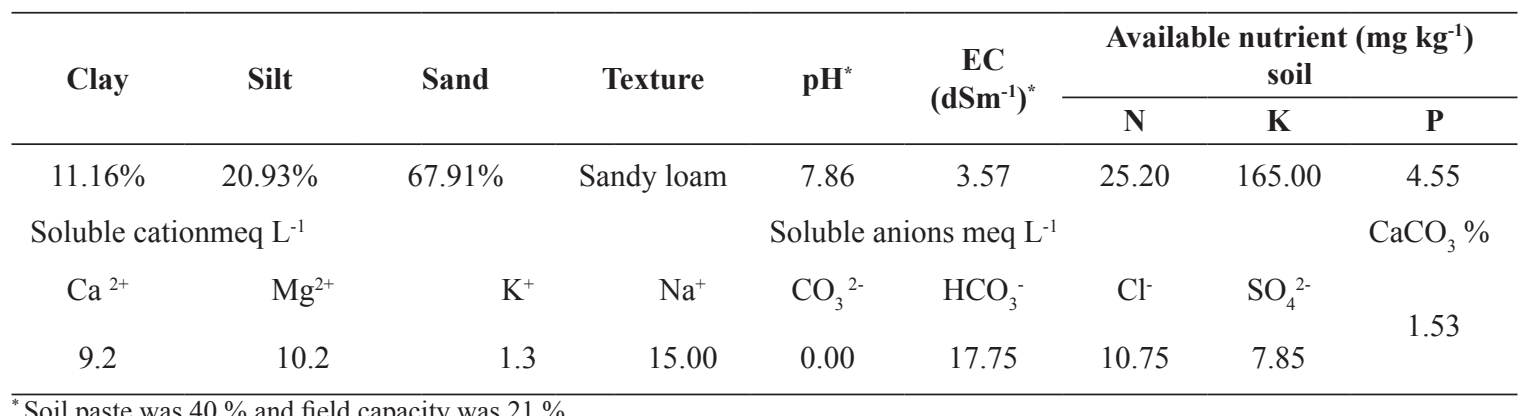

${ }^{*}$ Soil paste was $40 \%$ and field capacity was $21 \%$.

\section{The different used treatments}

Phosphorus fertilizers were used at three rates 0,14 and $28 \mathrm{~kg} \mathrm{P} \mathrm{fed}^{-1}$ as single super phosphate $(7 \% \mathrm{P})$ while, foliar application were the control (water only), $0.3 \%$ and $(0.6 \%)$ calcium as a calcium nitrate, $0.5 \%$ and $1 \%$ potassium in potassium nitrate. The experimental design consisted of three replications per treatment in a split block design. Soil preparation was adopted as recommended by the Ministry of Agriculture and Land Reclamation, Egypt and lined then seedlings were spaced $0.5 \mathrm{~m}$ between plants in a single row corresponding to approximately 40000 plant fed $^{-1}$. Tomatoes seedlings (Lycopersicon esculentum) Mill cv. Alisa Hybrid F1, were transplanted to the permanent soil on 27 December in each seasons. Plot area was $30 \mathrm{~m}^{2}$. Phosphorus treatments were added two weeks after seedling planting while the foliar applications were added at branching stage beginning about 45 day after seedling planting. Foliar applications treatments were added four times, 15 days between every spray.

\section{Data collection}

After a week from the last foliar spray a vegetative sample (five tomatoes leaves) were collected from each treatment, then fresh and dry weight and leaf area determined. At harvest, fruits of each treatment were collected to determine fruit yield and plant height. Four fruits were weighted as a means of the forth collection. Plant height was determined as average of ten plants. Tomatoes yield was calculated as a summation of yield of each plot in every collection* feddan area / (plot area). The N, P, K and calcium contents in fruit and vegetative samples were analyzed.

\section{Soil analyses}

Particle size distribution was determined using the international pipette method as described by Haluschak (2006). The soil electrical conductivity and soil $\mathrm{pH}$ values were determined in soil paste as described by Carter and Gregorich (2007). Field capacity and saturated percentage were determined as described by Black(1965).Available 
nitrogen in soil was extracted by using $2.0 \mathrm{~N} \mathrm{KCl}$ according to van Reeuwijk (2002) and determined using half automatic kjldhal apparatus while available phosphorus in the soil was extracted by using $0.5 \mathrm{~N} \mathrm{NaHCO}_{3}-\mathrm{pH}, 8.5$ according to van Reeuwijk (2002). Available potassium in soil was extracted using $1.0 \mathrm{~N}\left(\mathrm{CH}_{3}\right) \mathrm{COONH}_{3}$ according to Hesse (1971) and determined by using the Flame photometer Janways model PFP7 .

\section{Plant analysis}

Fruit and vegetative samples were oven dried $\left(70^{\circ} \mathrm{C}\right)$ until constant weight. The oven dry plant samples were ground and wet digested by a sulfuric - percloric acid mixture as described by Cottenie et al. (1982). Nitrogen, phosphorus and potassium contents of vegetative and fruit samples were measured in the digesting extract according to the methods of AOAC International (2012). Calcium content was determined in vegetative sample and fruit by ashing as described by Chapman and pratt (1978) extract method.

Nutrient uptake in $\mathrm{kg} \mathrm{fed}^{-1}$ equals Nutrient \% in leaves or fruits *dry matter of leaves or fruits in $\mathrm{kg} \mathrm{fed}^{-1} / 100$ (Sharma, et al., 2012).

Lycopene concentration ( $\mathrm{mg} \mathrm{kg}^{-1}$ fresh weight) in fruit was extracted as follows: samples were first chopped and homogenized in a laboratory homogenizer. Approximately 0.3 to $0.6 \mathrm{~g}$ samples were weighed and $5 \mathrm{ml}$ of $0.05 \%(\mathrm{w} / \mathrm{v})$ BHT in acetone, $5 \mathrm{ml}$ of ethanol and $10 \mathrm{ml}$ of hexane were added. The recipient was introduced in ice and stirred on a magnetic stirring plate for 15 min. After shaking, $3 \mathrm{ml}$ of deionized water were added to each vial and the samples were shaken for $5 \mathrm{~min}$ on ice. Samples were then left at room temperature for $5 \mathrm{~min}$ to allow the separation of both phase sand quantified spectrophotometrically at $472 \mathrm{~nm}$. Apparatus UV-Vis. Spectral analysis has been done using a Janways spectrophotometer (Ravelo-Pérez et al., 2008).

Lycopene content $(\mathrm{mg} / \mathrm{kg})=$ absorption reading at ${ }_{503} * 31.2 / \mathrm{g}$ tissue

\section{Statistical analysis}

All data were statistically analyzed according to the technique of analysis; variance (ANOVA), the least significant difference (LSD) method and correlation coefficient analysis were used to compare the difference between the means of treatment values to methods described by Gomez and Gomez (1984). Analysis of variance was done for each parameter at $\mathrm{P}<0.05$ using CoSTATE PC programming.

\section{Results and Discussion}

Vegetative growth parameters

Data presented in Table 2 illustrate that tomato plant height significantly increased with increasing phosphorus rates and the treatment of $28 \mathrm{~kg} \mathrm{P}^{-1} \mathrm{f}^{-1}$ gave the highest plant height values $(85.33$ and $86.40 \mathrm{~cm})$ in both seasons without significant differences with the recommended rate. These results are consistent with that of Sun et al. (2004). Foliar application treatments also significantly increased tomato plant height where, it increased by $14.45,8.89,12.40$ and $7.14 \%$ in the first season and 10.84, 7.52, 12.43 and $6.25 \%$ in the second season with the treatments $0.3 \%$, $0.6 \%$ calcium $(\mathrm{Ca}), 0.5 \%$ and $1 \%$ potassium $(\mathrm{K})$, respectively. These results may be because of calcium activating enzymes for cell mitosis, division and elongation (Jones,1999). The interaction between phosphorus treatments and foliar application treatments also significantly increased tomatoes plant height compared with the control. The treatment of $28 \mathrm{~kg} \mathrm{P}$ fed $^{-1}$ combined with $0.5 \% \mathrm{~K}$ followed by the treatment of $14 \mathrm{~kg} \mathrm{P} \mathrm{fed}^{-1}$ integrated with $0.3 \%$ Ca recorded the highest tomato plant height in both seasons.

On the other hand, phosphorus treatments significantly increased tomato leaf area $\left(\mathrm{cm}^{2}\right)$ and the recommended rate $\left(14 \mathrm{~kg} \mathrm{P} \mathrm{fed}^{-1}\right)$ gave the highest leaf area values (38.93 and $39.12 \mathrm{~cm}^{2}$ ). These results are in line with Sun et al. (2004) who found that leaf area $\mathrm{cm}^{2}$ increased linearly with the increase in the phosphorus rates. On the other side, foliar application treatments also significantly increased leaf area except with the treatment of $1 \% \mathrm{~K}$ and $0.6 \mathrm{Ca}$, it decreased significantly compared with the control.

The obtained results may be due to the role of $\mathrm{Ca}$ in cell division, mitosis and carbohydrate metabolism (Davis et al., 2003) and also potassium role in shoot elongation, enzyme activity, protein synthesis, photosynthetic transport, and chlorophyll content (Kanai et al., 2011). The foliar application of $0.5 \%$ potassium recorded the highest leaf area. Leaf area $\left(\mathrm{cm}^{2}\right)$ significantly increased by the interaction between treatments except with the treatment of $14 \mathrm{~kg} \mathrm{P}$ fed $^{-1}$ and $1 \% \mathrm{~K}$ compared with the control.The best leaf area values were 44 and $44.38 \mathrm{~cm}^{2}$ found at the interaction between $14 \mathrm{~kg} \mathrm{P} \mathrm{fed}^{-1}$ and $0.6 \%$ calcium as a foliar treatment. 
TABLE 2. Effect of foliar application of potassium and calcium nitrate and soil phosphorus treatments on plant height $(\mathrm{cm})$, leaf area $\left(\mathrm{cm}^{2}\right)$, fresh weight $(\mathrm{g})$ and dry weight $(\mathrm{g})$ of tomato leaf samples during the $1^{\text {st }}$ and $2^{\text {nd }}$ seasons.

\begin{tabular}{|c|c|c|c|c|c|c|c|c|c|}
\hline \multirow{2}{*}{\multicolumn{2}{|c|}{$\begin{array}{l}\text { Treat. } \\
\text { Char. }\end{array}$}} & \multicolumn{2}{|c|}{ Plant height(cm) } & \multicolumn{2}{|c|}{ Leaf area $\left(\mathrm{cm}^{2}\right)$} & \multicolumn{2}{|c|}{ Fresh weight(g) } & \multicolumn{2}{|c|}{ Dry weight (g) } \\
\hline & & $1^{\text {st }}$ & $2^{\text {nd }}$ & $1^{\text {st }}$ & $2^{\text {nd }}$ & $1^{\text {st }}$ & $2^{\text {nd }}$ & $1^{\text {st }}$ & $2^{\text {nd }}$ \\
\hline \multicolumn{10}{|c|}{ Phosphorus levels } \\
\hline \multicolumn{2}{|l|}{$0 \mathrm{~kg} P$} & $79.66 \mathrm{~b}$ & $78.95 \mathrm{c}$ & $31.26 \mathrm{c}$ & $32.03 \mathrm{c}$ & $64.21 \mathrm{c}$ & $65.78 \mathrm{c}$ & $13.49 \mathrm{c}$ & $13.80 \mathrm{a}$ \\
\hline \multicolumn{2}{|l|}{14 kg P } & $82.93 \mathrm{ab}$ & $84.00 \mathrm{~b}$ & $38.932 \mathrm{a}$ & $39.12 \mathrm{a}$ & $80.54 a$ & $80.92 \mathrm{a}$ & $15.17 \mathrm{a}$ & $14.96 \mathrm{a}$ \\
\hline \multicolumn{2}{|l|}{$28 \mathrm{~kg} \mathrm{P}$} & $85.33 \mathrm{a}$ & $86.40 \mathrm{a}$ & $33.75 b$ & $34.16 b$ & $70.61 \mathrm{~b}$ & $71.45 b$ & $13.93 b$ & $13.91 \mathrm{a}$ \\
\hline \multicolumn{2}{|l|}{ LSD at $5 \%$} & 3.76 & 1.86 & 0.43 & 0.94 & 0.92 & 1.96 & 0.16 & Ns \\
\hline \multicolumn{10}{|c|}{ Foliar treatment } \\
\hline \multicolumn{2}{|l|}{ Control } & $76.11 \mathrm{c}$ & $77.38 b$ & $34.93 b$ & $35.61 b$ & $66.09 \mathrm{~d}$ & $67.41 \mathrm{~d}$ & $13.34 \mathrm{c}$ & $13.42 \mathrm{~b}$ \\
\hline \multicolumn{2}{|l|}{$0.3 \% \mathrm{Ca}$} & $87.11 \mathrm{a}$ & $85.77 \mathrm{a}$ & $35.05 \mathrm{~b}$ & $35.47 b$ & $74.37 \mathrm{~b}$ & $75.27 \mathrm{~b}$ & $14.36 \mathrm{ab}$ & $14.34 \mathrm{ab}$ \\
\hline \multicolumn{2}{|l|}{$0.6 \% \mathrm{Ca}$} & $82.88 \mathrm{~b}$ & $83.20 \mathrm{a}$ & $34.35 \mathrm{c}$ & $34.61 \mathrm{c}$ & $71.62 \mathrm{c}$ & $72.16 \mathrm{c}$ & $14.25 b$ & $14.29 \mathrm{ab}$ \\
\hline \multicolumn{2}{|l|}{$0.5 \% \mathrm{~K}$} & $85.55 \mathrm{a}$ & $87.00 \mathrm{a}$ & $36.68 \mathrm{a}$ & $37.20 \mathrm{a}$ & $75.72 \mathrm{a}$ & $76.78 \mathrm{a}$ & $14.69 \mathrm{a}$ & $14.72 \mathrm{a}$ \\
\hline \multicolumn{2}{|l|}{$1 \% \mathrm{~K}$} & $81.55 \mathrm{~b}$ & $82.22 \mathrm{a}$ & $32.23 \mathrm{~d}$ & $32.61 \mathrm{~d}$ & $71.13 \mathrm{c}$ & $71.97 \mathrm{c}$ & $14.33 \mathrm{ab}$ & $14.34 \mathrm{ab}$ \\
\hline \multicolumn{2}{|l|}{ LSD at $5 \%$} & 2.13 & 3.67 & 0.56 & 0.43 & 1.19 & 0.94 & 0.32 & 0.39 \\
\hline \multicolumn{10}{|c|}{ Interaction } \\
\hline \multirow{4}{*}{$0 \mathrm{~kg} P$} & Control & $70.00 \mathrm{e}$ & $70.16 f$ & $28.40 \mathrm{k}$ & $29.39 \mathrm{i}$ & $54.34 \mathrm{k}$ & $56.23 \mathrm{i}$ & $11.87 \mathrm{~h}$ & $12.48 \mathrm{f}$ \\
\hline & $0.3 \% \mathrm{Ca}$ & $86.33 \mathrm{ab}$ & $80.33 \mathrm{de}$ & $28.09 \mathrm{k}$ & $28.90 \mathrm{i}$ & $60.91 \mathrm{j}$ & $62.67 \mathrm{~h}$ & $12.64 \mathrm{~g}$ & $13.49 \mathrm{de}$ \\
\hline & $0.6 \% \mathrm{Ca}$ & $78.66 \mathrm{~d}$ & $79.26 \mathrm{e}$ & $31.36 \mathrm{ij}$ & $32.17 \mathrm{~g}$ & $64.00 \mathrm{i}$ & $65.66 \mathrm{~g}$ & $13.64 \mathrm{ef}$ & $13.60 \mathrm{de}$ \\
\hline & $0.5 \% \mathrm{~K}$ & $81.66 \mathrm{~cd}$ & $82.66 \mathrm{cde}$ & $36.14 \mathrm{de}$ & $36.58 \mathrm{~d}$ & $73.75 \mathrm{de}$ & $74.65 \mathrm{de}$ & $14.74 \mathrm{bc}$ & $14.75 \mathrm{~b}$ \\
\hline \multirow{6}{*}{14 kg P } & $1 \% \mathrm{~K}$ & $81.66 \mathrm{~cd}$ & $82.33 \mathrm{cde}$ & $32.33 \mathrm{hi}$ & $33.11 \mathrm{f}$ & $68.05 \mathrm{~h}$ & $69.70 \mathrm{f}$ & $14.58 \mathrm{bcd}$ & $14.69 \mathrm{~b}$ \\
\hline & Control & $80.00 \mathrm{~d}$ & $80.66 \mathrm{cde}$ & $36.34 d$ & $36.59 \mathrm{~d}$ & $75.76 \mathrm{~cd}$ & $76.42 \mathrm{c}$ & $14.87 \mathrm{~b}$ & $14.48 \mathrm{~b}$ \\
\hline & $0.3 \% \mathrm{Ca}$ & $90.00 \mathrm{a}$ & $90.33 \mathrm{ab}$ & $42.81 \mathrm{~b}$ & $42.77 b$ & $90.10 \mathrm{a}$ & $90.03 \mathrm{a}$ & $16.35 \mathrm{a}$ & $15.45 \mathrm{a}$ \\
\hline & $0.6 \% \mathrm{Ca}$ & $81.66 \mathrm{~cd}$ & $83.33 \mathrm{cde}$ & $44.00 \mathrm{a}$ & $44.38 \mathrm{a}$ & $76.48 \mathrm{c}$ & $77.01 \mathrm{c}$ & $14.59 \mathrm{bcd}$ & $14.76 \mathrm{~b}$ \\
\hline & $0.5 \% \mathrm{~K}$ & $85.00 \mathrm{bc}$ & 86.33abcd & $40.52 \mathrm{c}$ & $40.51 \mathrm{c}$ & $85.28 \mathrm{~b}$ & $85.26 \mathrm{~b}$ & $15.84 \mathrm{a}$ & $15.42 \mathrm{a}$ \\
\hline & $1 \% \mathrm{~K}$ & $78.00 \mathrm{~d}$ & $79.33 \mathrm{e}$ & $30.98 \mathrm{j}$ & $31.32 \mathrm{~h}$ & $75.10 \mathrm{~cd}$ & $75.90 \mathrm{~cd}$ & $14.20 \mathrm{~cd}$ & $14.20 \mathrm{bc}$ \\
\hline \multirow{5}{*}{28 kg P } & Control & $78.33 d$ & $81.33 \mathrm{cde}$ & $32.40 \mathrm{gh}$ & $33.05 \mathrm{f}$ & $68.18 \mathrm{gh}$ & $69.56 \mathrm{f}$ & $13.30 \mathrm{f}$ & $13.32 \mathrm{e}$ \\
\hline & $0.3 \% \mathrm{Ca}$ & $85.00 \mathrm{bc}$ & 86.66abcd & $34.26 \mathrm{f}$ & $34.73 \mathrm{e}$ & $72.10 \mathrm{ef}$ & $73.10 \mathrm{e}$ & $14.10 \mathrm{de}$ & $14.21 b c$ \\
\hline & $0.6 \% \mathrm{Ca}$ & $88.33 \mathrm{ab}$ & $87.00 \mathrm{abc}$ & $35.34 \mathrm{e}$ & $35.06 \mathrm{e}$ & $74.39 \mathrm{~d}$ & $73.80 \mathrm{e}$ & $14.64 \mathrm{bcd}$ & $14.53 b$ \\
\hline & $0.5 \% \mathrm{~K}$ & $90.00 \mathrm{a}$ & $92.00 \mathrm{a}$ & $33.39 \mathrm{f}$ & $34.51 \mathrm{e}$ & $68.15 \mathrm{~h}$ & $70.44 \mathrm{f}$ & $13.50 \mathrm{f}$ & $13.65 \mathrm{cde}$ \\
\hline & $1 \% \mathrm{~K}$ & $85.00 \mathrm{bc}$ & $85.00 \mathrm{bcde}$ & $33.37 \mathrm{fg}$ & $33.41 \mathrm{f}$ & $70.23 \mathrm{fg}$ & 70.33 & $14.21 \mathrm{~cd}$ & $14.12 \mathrm{bcd}$ \\
\hline \multicolumn{2}{|l|}{ LSD at $5 \%$} & 3.68 & 6.35 & 0.97 & 0.76 & 2.05 & 1.63 & 0.55 & 0.67 \\
\hline
\end{tabular}

Leaves fresh weight $(g)$

From the obtained data in Table 2, fresh weight of tomato leaves significantly increased with phosphorus levels and the treatment of $14 \mathrm{~kg}$ $\mathrm{P} \mathrm{fed}^{-1}$ gave the highest fresh weight values $(80.54$ and $80.92 \mathrm{~g}$ ) in both seasons. These results may be regarded to phosphorus role in photosynthesis, the process by which plants harvest energy from the sun to produce carbohydrate molecules, i.e. sugars. These results are consistent with Groot et al. (2002). Otherwise, the foliar application treatments increased significantly tomato fresh weight. It was observed that the lower concentration of foliar materials enhanced plant fresh weight than the higher concentration. These results may be due to the increase of leaf area $\left(\mathrm{cm}^{2}\right)$ by foliar treatments highly correlated with fresh weight $(\mathrm{r}=0.82$ and $\mathrm{r}=0.82, P<0.05$ level $)$ in both seasons. The best fresh weight values were recorded at the treatment of $0.5 \%$ potassium as a foliar spray in both seasons. These results are consistent with Bidari and Hebsur (2011). A similar trend was found by the interaction between phosphorus treatments and foliar treatments on fresh weight which increased significantly by this interaction compared with thecontrol and

Egypt. J. Soil Sci., 58, No.1 (2018) 
the best values of tomatoes fresh weight were 90.1 and $90.03 \mathrm{~g}$ found at the treatment of 14 $\mathrm{kg} \mathrm{P}$ fed $^{-1}$ and $0.3 \% \mathrm{Ca}$ as calcium nitrate form. These results may be due to the phosphorus role in root growth and photosynthesis and calcium role in the maintenance of cell membrane integrity, membrane permeability and growth (Morard et al., 1996).

Dry weight of leaves took the same trend in both seasons where, phosphorus, foliar application treatments and its interaction significantly increased dry weight whereas phosphorus rate effects in the second season were not significant.

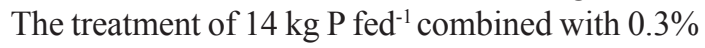
$\mathrm{Ca}$ gave the best dry weight values (16.35 and $15.45 \mathrm{~g}$ ) of the vegetative sample in both seasons.

Nitrogen, $P, K$ and Ca contents in tomato leaves

As shown in Table 3 nitrogen content in tomato leaves significantly decreased with increasing phosphorus rates upto $28 \mathrm{~kg} \mathrm{P} \mathrm{fed}{ }^{-1}$, while the foliar application treatments significantly increased nitrogen content (\%) in leaves in both seasons. The calcium foliar application treatment recorded the best nitrogen content in tomato leaves in both seasons and the highest nitrogen content values were 4.55 and 5.01 found at the treatment of $0.3 \%$ calcium. Data also illustrate that the lower concentration of foliar application materials gave the best results than the higher concentrations. On the other hand, the interaction between phosphorus treatments and foliar treatments significantly increased nitrogen content in tomatoes leaves compared with the control treatment whereas the interaction between $28 \mathrm{~kg} \mathrm{P}$ fed $^{-1}$ and $1 \% \mathrm{k}$ as foliar application decreased nitrogen content. The integration between $0.6 \%$ calcium and phosphorus treatments (14 and $\left.28 \mathrm{~kg} \mathrm{P} \mathrm{fed}^{-1}\right)$ recorded the highest nitrogen content values (4.83 and 5.31\%) in the two successive seasons, respectively.

Data in Table 3 show that phosphorus content $(\%)$ in tomato leaves significantly decreased with increasing phosphorus rates. These results may be due to dilution effect where, the concentration decreased when the growth increased. While the foliar application treatments significantly increased phosphorus content at the lower concentration of foliar application materials and it decreased at the higher concentrations. The obtained data may be due to, at nutrient balance, the little nutrient concentration encourages phosphorus uptake in contrast with higher concentrations.

TABLE 3. Effect of foliar application of potassium and calcium nitrate and soil phosphorus treatments on N, P, K and Ca content (\%) of tomato leaves during the $1^{\text {st }}$ and $2^{\text {nd }}$ seasons

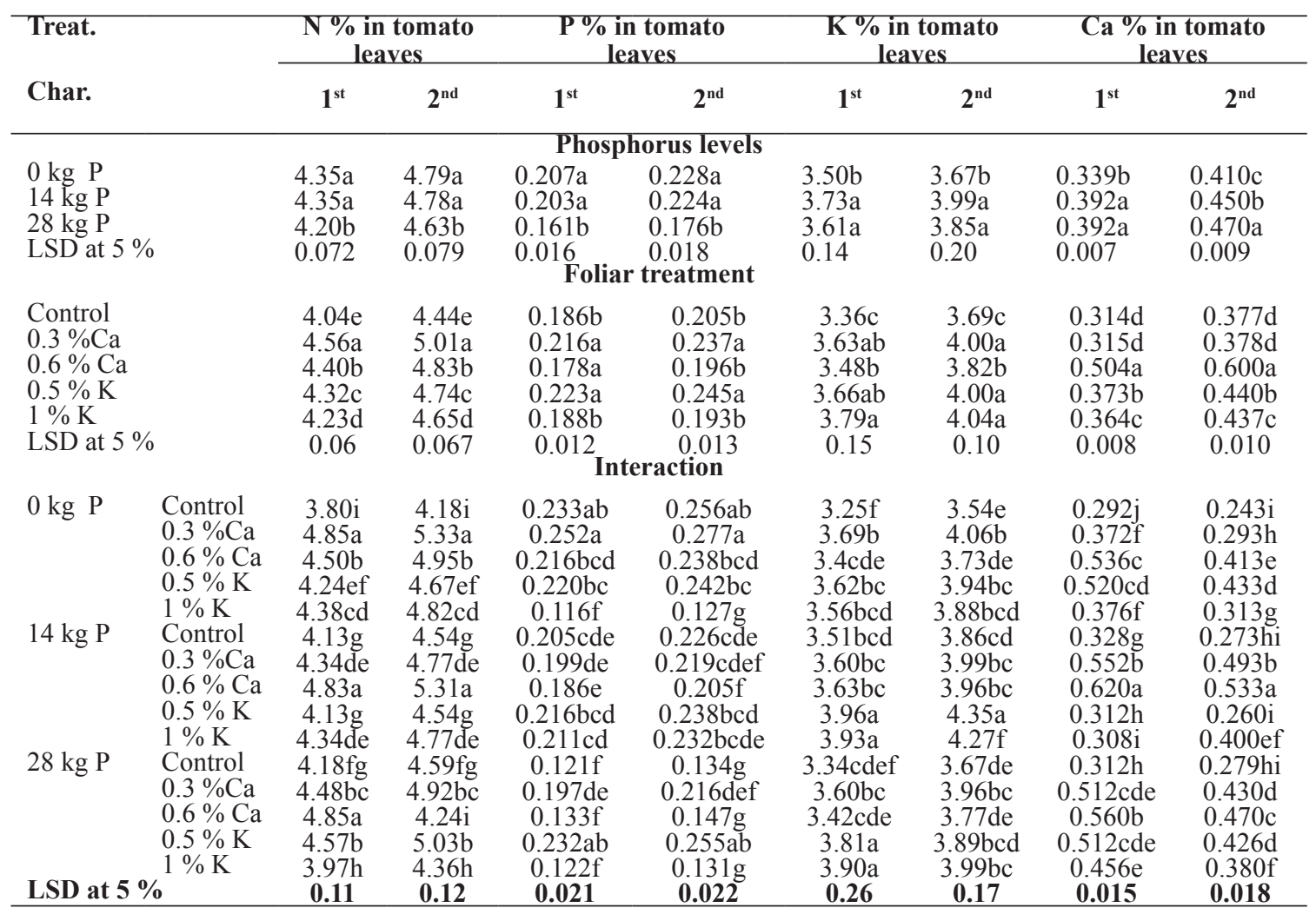

Egypt. J. Soil Sci., 58, No.1 (2018) 
The highest phosphorus contents were 0.223 and $0.245 \%$ recorded at the foliar application of $0.5 \%$ potassium in both seasons. On the other side, the phosphorus content (\%) was significantly affected by the interaction between different treatments. It was observed that with increasing phosphorus rate integrated with foliar calcium treatments, phosphorus content decreased compared with the control treatment. These results may be regarded to antagonism between phosphorus and calcium which declare from the negative correlation $(\mathrm{r}=-0.5, P<0.05$ level).

Potassium content (\%) in tomato leaves shows that phosphorus treatment significantly increased potassium content up to $28 \mathrm{~kg} \mathrm{P} \mathrm{fed}^{-1}$ and the treatment of $14 \mathrm{~kg} \mathrm{P}^{-1} \mathrm{~d}^{-1}$ gave the highest potassium content values (3.73 and 3.99\%). The same trend was found with foliar treatments where, potassium content increased significantly with the foliar application treatments and the increment was higher at the high concentration of $0.6 \mathrm{Ca}$ and $1 \% \mathrm{~K}$ compared to the low concentration of foliar application treatments. The results are in line with Kazemi (2014) who found that potassium application alone significant increased leaf-NPK contents and chlorophyll content. Also, these results may be due to the increased plant leaf area as affected by foliar treatment which correlated with potassium content by $(\mathrm{r}=0.37$ and $0.34, P<0.05$ level) in both seasons, respectively. Potassium content also significantly increased by the interaction between phosphorus treatment and foliar application treatments compared with the control.The treatment of $14 \mathrm{~kg} \mathrm{P}^{\mathrm{P}} \mathrm{fed}^{-1}$ and $0.5 \%$ potassium recorded the highest potassium content $(\%)$ in both seasons. These results may be caused by the response of plants grown in poor sandy soil to phosphorus fertilizer and foliar application with calcium and potassium.

Data in Table 3 illustrate that calcium content in tomatoe leaves significantly increased with increasing phosphorus rate in both seasons and the treatment of $28 \mathrm{~kg} \mathrm{P} \mathrm{fed}^{-1}$ gave the highest calcium content in both seasons. These results may be because phosphorus fertilizers contained a higher amount from calcium as a secondary nutrient with those fertilizers. A similar trend was found with the foliar application treatments where, it increased with different foliar application treatments and the increment was higher in calcium treatments than potassium treatments. The treatment of $0.6 \%$ calcium as a foliar application gave the highest calcium content values $(0.5$ and $0.6 \%)$ in both seasons, respectively. On the other hand, calcium content (\%) was significantly affected by the interaction between the different treatments. The highest calcium content values were 0.62 and $0.53 \%$ found at the treatment of $14 \mathrm{~kg} \mathrm{P} \mathrm{fed}^{-1}$ combined with $0.6 \%$ calcium as foliar spray. These results may be regarded to the effects of foliar nutrition which stimulates the intake of mineral nutrient by roots (Adamec, 2002).

\section{Tomato yield and fruit nutrients uptake}

Concerning tomato yield $\left(\mathrm{Mg} \mathrm{fed}^{-1}\right)$, weight of four fruit, fruit length and fruit diameter data in Table 4 illustrate that all used treatments significantly affected the aforementioned parameters. Where the fresh weight of four fruit increased with increasing phosphorus rate and the highest values were found with $14 \mathrm{~kg} \mathrm{P}$ fed $^{-1}$ in both seasons. Similar direction was found also with foliar application treatments but the increment in weight of four fruits was higher in the low concentration than the higher concentration. These results may be due to the role of calcium and potassium on photosynthesis, enzyme activation, leaf area $\left(\mathrm{cm}^{2}\right)$ cell turgor maintenance and ion homeostasis (Marshner, 1995). The obtained results agree with Anac et al. (1994) and Afzal et al. (2015). The highest weights of four fruits values were 450 and $455.6 \mathrm{~g}$ recorded with the interaction between $14 \mathrm{~kg} \mathrm{P}^{\mathrm{P}} \mathrm{fed}^{-1}$ and foliar application with calcium nitrate at $0.3 \%$. Fruit diameter increased with the recommended phosphorus dose than the other treatments in both seasons. While it increased with foliar application of $0.3 \% \mathrm{Ca}, 0.6 \%, 0.5 \mathrm{~K}$ and $1 \% \mathrm{~K}$ by 7.50 , $4.05,12.77$ and $8.72 \%$ in the first season and by $8.5,6.23,13.09$ and $10.60 \%$ in the second season, respectively compared to the control. Data also show that the lower concentration of foliar application materials achieve a high increase than the higher concentration. The treatment of $0.5 \%$ $\mathrm{K}$ as potassium nitrate recorded the highest fruit width values $(5.6$ and $5.44 \mathrm{~cm}$ ) in both seasons while the interaction between $14 \mathrm{~kg} \mathrm{P} \mathrm{fed}^{-1}$ and 0.5 $\% \mathrm{~K}$ recoded the best fruit diameter values ( 6 and $6.1 \mathrm{~cm}$ ) in both seasons, respectively.

Tomatoe yield ( $\left.\mathrm{Mg} \mathrm{fed}^{-1}\right)$

From the obtained data shown in Table 4, Tomato yield $\left(\mathrm{Mg} \mathrm{fed}^{-1}\right)$ significantly increased with increasing phosphorus rate up to $14 \mathrm{~kg} \mathrm{P}$ fed $^{-1}$ then decreased compared with the control treatment. These results are consistent with those of Dhinakaran and Savithri (1997) and Idowu et al. (2013) who stated that phosphorus levels

Egypt. J. Soil Sci., 58, No.1 (2018) 
significantly increased growth, yield and yield components of snake tomato at $15 \mathrm{~kg} \mathrm{ha}^{-1}$ up to 30 $\mathrm{kg} \mathrm{P} \mathrm{ha}{ }^{-1}$. This result is almost similar to Pandey et al. (1996). They reported that fruit yield was increased with the increasing rates of phosphorus. On the other hand, foliar application treatment also significantly increased tomato yield $(\mathrm{Mg}$ $\mathrm{fed}^{-1}$ ), where it increased by $13.50,1.49,19.85$ and $12.23 \%$ in the first season and 17.32, 5.08, 23.55 and $15.93 \%$ in the second season with the treatments of $0.3 \%, 0.6 \%$ calcium, $0.5 \%$ and $1 \%$ potassium, respectively. The increment was higher with the low concentration of foliar application materials than the high concentration. These results are consistent with that of Shafeek et al. (2013). However the interaction between phosphorus treatment and foliar treatments significantly affected tomato yield $\left(\mathrm{Mg} \mathrm{fed}^{-1}\right)$ where, in the lower phosphorus rate $(0 \mathrm{P})$ foliar application treatment led to increased tomatoe yield $\left(\mathrm{Mg} \mathrm{fed}^{-1}\right)$ compared to the control (OP and 0 foliar) while, at the rate of $14 \mathrm{~kg} \mathrm{P} \mathrm{fed}^{-1}$, the yield increased also except with the treatment of $0.6 \%$ calcium which decreased tomatoe yield. These results may be regarded to the high calcium content in soil from single super phosphates which contain a big amount of calcium and antagonism between phosphorus and calcium. The results agree with Peyvast, et al. (2009) who revealed different effects of calcium nitrate and potassium phosphate as foliar nutrition and the interaction of these fertilizers on the yield and quality of tomato. The highest tomato yield values (18 and $18.06 \mathrm{Mg} \mathrm{fed}^{-1}$ ) were recorded with the treatment of $14 \mathrm{~kg} \mathrm{P} \mathrm{fed}^{-1}$ combined with $0.3 \%$ calcium as a foliar application followed by $14 \mathrm{~kg} \mathrm{P} \mathrm{fed}^{-1}$ and $0.5 \%$ potassium as a foliar application which recorded 17.36 and $17.32 \mathrm{Mg} \mathrm{fed}^{-1}$, respectively in both seasons. This increased fruit yield with $\mathrm{K}$ supply might be due to phloem loading, unloading efficient translocation of assimilates towards sink tissues (Zhao et al., 2001). These results agree with that of Ilyas et al. (2014).

TABLE 4. Effect of foliar application of potassium and calcium nitrate and soil phosphorus treatments on fresh weight of four fruit, fruit diameter, fruit length $(\mathrm{cm})$ and tomato yield $\left(\mathrm{Mg} \mathrm{fed}^{-1}\right)$ during the $1^{\text {st }}$ and $2^{\text {nd }}$ seasons

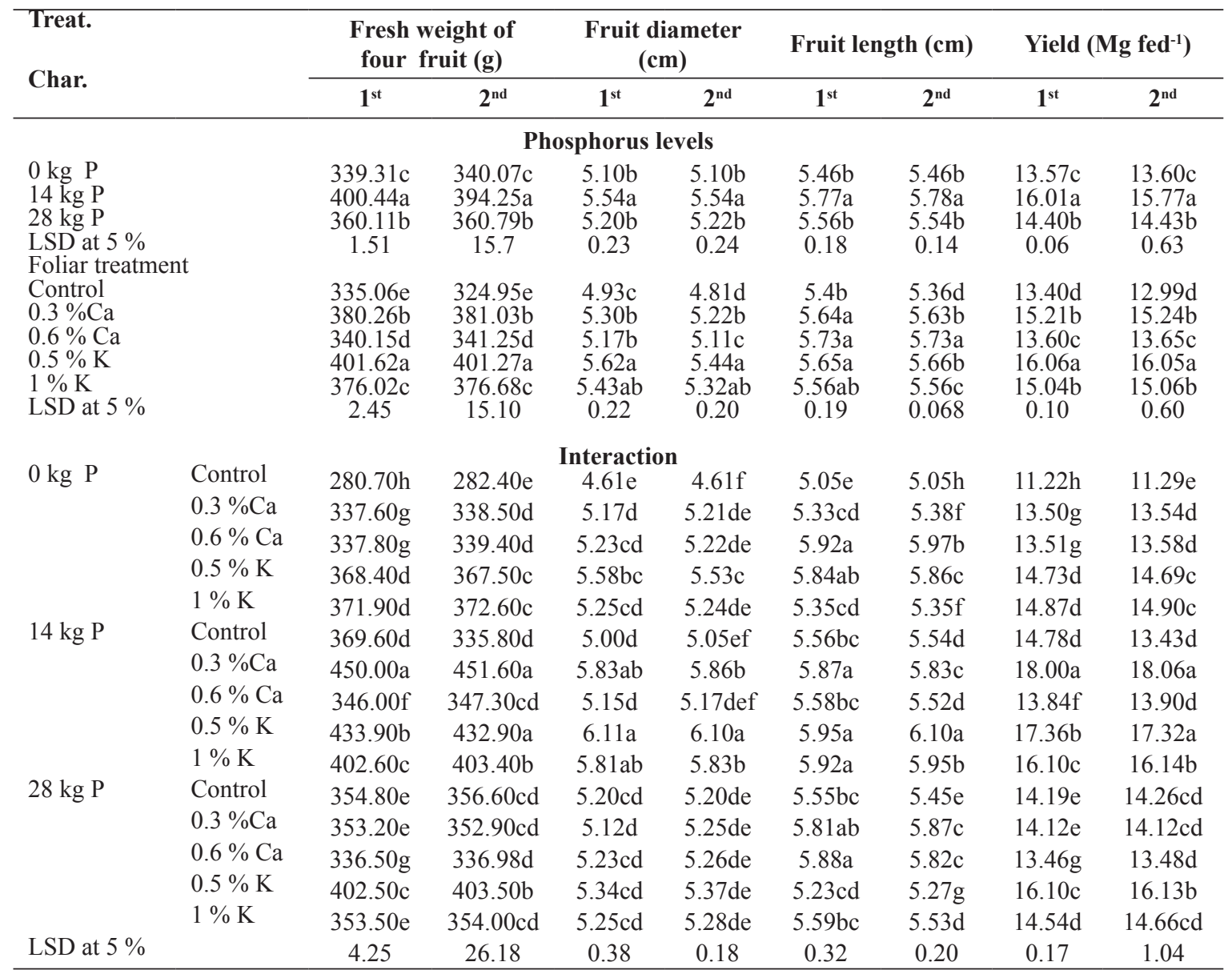

Note: $\mathrm{Mg}$ is a weight unit and equal $1000 \mathrm{~kg}$ or one ton. 
Nitrogen, $P, K$ and Ca contents on tomatoes fruits

Data in Table 5 show that nitrogen uptake by tomatoe fruits significantly increased with increasing phosphorus rate and also increased with different foliar application treatments in both seasons. The foliar treatment of $0.5 \%$ potassium gave the highest nitrogen uptake by fruits in both seasons. The results agree with Shafeek et al. (2013). On the other hand, the interaction between different treatments significantly influenced nitrogen uptake and the highest nitrogen uptake values ( 35.83 and $39.50 \mathrm{~kg} \mathrm{~N}$ fed $^{-1}$ ) were obtained by the interaction between $28 \mathrm{~kg} \mathrm{P}$ fed $^{-1}$ and $0.5 \%$ potassium as a foliar spray. From the obtained data it was observed that at the low phosphorus rate nitrogen uptake increased with different foliar application treatment in both seasons while it decreased with increasing phosphorus rate up to $28 \mathrm{~kg} \mathrm{P}^{\mathrm{P}} \mathrm{fe}^{-1}$ except with the treatments of $28 \mathrm{~kg} \mathrm{P} \mathrm{fed}^{-1}$ and $0.5 \%$ or $1 \%$ potassium. Data presented in Table 5 declare that phosphorus uptake by tomato fruits increased with increasing phosphorus rate and the increased with $28 \mathrm{~kg} \mathrm{P}$ fed $^{-1}$ and the increment was less than with the treatment of $14 \mathrm{~kg} \mathrm{P} \mathrm{fed}^{-1}$.These results agree with Dhinakaran and Savithri (1997) who reported that phosphorus treatment applied at $100 \mathrm{~kg} \mathrm{P}_{2} \mathrm{O}_{5}$ ha $^{-1}$ significantly increased the yield of tomatoes. Phosphorus content and phosphorus uptake of tomato fruit increased with the increased application of phosphorus . Also, foliar application treatments significantly increased phosphorus uptake by tomato fruits compared with the control treatment except with the treatment of $0.6 \%$ calcium. While, the interaction between different treatments significantly increased phosphorus uptake by fruits whereaswith the treatments of 0.3 and $0.6 \%$ calcium with 0 and $14 \% \mathrm{~kg} \mathrm{P} \mathrm{fed}^{-1}$ it decreased.The highest phosphorus uptake values by tomato fruits were found with the treatment of $14 \mathrm{~kg} \mathrm{P} \mathrm{fed}^{-1}$ combined with $0.5 \%$ potassium as a foliar application.

Potassium uptake by tomato fruits

TABLE 5. Effect of foliar application of potassium and calcium nitrate and soil phosphorus treatment on N, P, K, Ca uptake by tomatoes fruits $\left(\mathrm{kg} \mathrm{fed}^{-1}\right)$ and lycopene content $\left(\mathrm{mgkg}^{-1}\right)$ during the $1^{\text {st }}$ and $2^{\text {nd }}$ seasons.

\begin{tabular}{|c|c|c|c|c|c|c|c|c|c|c|c|}
\hline \multirow{2}{*}{ Treat. } & \multirow{2}{*}{ Char. } & \multicolumn{2}{|c|}{$\mathbf{N}$} & \multicolumn{2}{|c|}{$\mathbf{P}$} & \multicolumn{2}{|c|}{$\mathbf{K}$} & \multicolumn{2}{|c|}{$\mathrm{Ca}$} & \multicolumn{2}{|c|}{$\begin{array}{c}\text { Lycopene (mgkg- } \\
1 \text { - }\end{array}$} \\
\hline & & $1^{\text {st }}$ & $2^{\text {nd }}$ & $1^{\text {st }}$ & $2^{\text {nd }}$ & $1^{\text {st }}$ & $2^{\text {nd }}$ & $1^{\text {st }}$ & $2^{\text {nd }}$ & $1^{\text {st }}$ & $2^{\text {nd }}$ \\
\hline \multicolumn{12}{|c|}{ Phosphorus levels } \\
\hline \multicolumn{2}{|l|}{$0 \mathrm{~kg} \mathrm{P}$} & $20.56 c$ & $22.75 \mathrm{c}$ & $2.43 \mathrm{c}$ & $2.07 \mathrm{c}$ & $28.40 \mathrm{c}$ & $27.57 b$ & $2.92 \mathrm{c}$ & $3.52 \mathrm{c}$ & $84.26 \mathrm{a}$ & $92.69 \mathrm{a}$ \\
\hline \multicolumn{2}{|l|}{$14 \mathrm{~kg} \mathrm{P}$} & $24.92 b$ & $26.91 \mathrm{~b}$ & $3.68 \mathrm{a}$ & $3.06 \mathrm{a}$ & $35.19 \mathrm{a}$ & $33.35 \mathrm{a}$ & $3.25 b$ & $4.06 \mathrm{~b}$ & $60.51 \mathrm{c}$ & $66.56 \mathrm{c}$ \\
\hline \multicolumn{2}{|l|}{$28 \mathrm{~kg} \mathrm{P}$} & $26.69 \mathrm{a}$ & $29.41 \mathrm{a}$ & $3.06 \mathrm{~b}$ & $2.59 \mathrm{~b}$ & $33.69 \mathrm{~b}$ & $32.58 \mathrm{c}$ & $3.70 \mathrm{a}$ & $4.36 \mathrm{a}$ & $72.89 b$ & $80.18 b$ \\
\hline \multicolumn{2}{|c|}{ LSD at $5 \%$} & 0.28 & 1.22 & 0.16 & 0.15 & 1.004 & 2.10 & 0.21 & 0.14 & 0.94 & 1.04 \\
\hline \multicolumn{12}{|c|}{ Foliar treatment } \\
\hline \multicolumn{2}{|l|}{ Control } & $21.81 \mathrm{e}$ & $23.91 \mathrm{c}$ & $2.74 d$ & $2.23 \mathrm{~d}$ & $28.12 d$ & $26.21 \mathrm{c}$ & $2.78 \mathrm{~d}$ & $3.16 \mathrm{~d}$ & $61.61 \mathrm{e}$ & $67.77 \mathrm{e}$ \\
\hline \multicolumn{2}{|l|}{$0.3 \% \mathrm{Ca}$} & $22.5 \mathrm{~d}$ & $24.04 \mathrm{c}$ & $2.98 \mathrm{c}$ & $2.52 \mathrm{c}$ & $30.26 \mathrm{c}$ & $29.46 b$ & $2.71 \mathrm{~d}$ & $3.30 \mathrm{~d}$ & $84.55 a$ & $93.00 \mathrm{a}$ \\
\hline \multicolumn{2}{|l|}{$0.6 \% \mathrm{Ca}$} & $23.20 \mathrm{c}$ & $25.61 b$ & $2.08 \mathrm{e}$ & $1.76 \mathrm{e}$ & $28.52 d$ & $27.55 \mathrm{c}$ & $4.02 \mathrm{~b}$ & $4.86 \mathrm{~b}$ & $80.24 b$ & $88.26 b$ \\
\hline \multicolumn{2}{|l|}{$0.5 \% \mathrm{~K}$} & $28.68 \mathrm{a}$ & $31.67 \mathrm{a}$ & $3.99 \mathrm{a}$ & $3.39 \mathrm{a}$ & $37.09 \mathrm{~b}$ & $35.85 \mathrm{a}$ & $3.59 \mathrm{a}$ & $4.57 \mathrm{a}$ & $67.41 \mathrm{~d}$ & $74.15 d$ \\
\hline \multicolumn{2}{|l|}{$1 \% \mathrm{~K}$} & $24.09 \mathrm{~b}$ & $26.55 b$ & $3.48 \mathrm{~b}$ & $2.96 \mathrm{~b}$ & $38.14 \mathrm{a}$ & $36.77 \mathrm{a}$ & $3.33 \mathrm{c}$ & $4.00 \mathrm{c}$ & $68.96 \mathrm{c}$ & $75.86 c$ \\
\hline \multicolumn{2}{|c|}{ LSD at $5 \%$} & 0.49 & 1.37 & 0.14 & 0.19 & 0.96 & 1.66 & 0.17 & 0.16 & 1.16 & 1.27 \\
\hline \multicolumn{12}{|c|}{ Interaction } \\
\hline \multirow{4}{*}{$0 \mathrm{~kg} \mathrm{P}$} & Control & $15.16 \mathrm{k}$ & $16.78 \mathrm{~g}$ & $2.17 \mathrm{~g}$ & $1.85 \mathrm{fg}$ & $22.56 \mathrm{k}$ & $21.85 \mathrm{~h}$ & $1.71 \mathrm{i}$ & $2.12 \mathrm{i}$ & $67.44 \mathrm{~g}$ & $74.18 \mathrm{~g}$ \\
\hline & $0.3 \% \mathrm{Ca}$ & $17.97 \mathrm{j}$ & $19.82 f$ & $1.96 \mathrm{ghi}$ & $1.66 \mathrm{gh}$ & $24.56 \mathrm{j}$ & $24.10 \mathrm{gh}$ & $3.01 \mathrm{e}$ & $3.71 \mathrm{f}$ & $95.29 \mathrm{a}$ & $104.81 \mathrm{a}$ \\
\hline & $0.6 \% \mathrm{Ca}$ & $23.48 \mathrm{gh}$ & $25.95 \mathrm{~cd}$ & $1.88 \mathrm{hi}$ & $1.59 \mathrm{gh}$ & 28.64hi & $27.69 \mathrm{ef}$ & $4.53 \mathrm{a}$ & $5.63 \mathrm{a}$ & $91.86 \mathrm{~b}$ & $101.0 \mathrm{~b}$ \\
\hline & $0.5 \% \mathrm{~K}$ & $25.8 \mathrm{~cd}$ & $28.72 b$ & $3.46 \mathrm{e}$ & $2.96 \mathrm{~cd}$ & $35.05 \mathrm{~d}$ & $34.16 \mathrm{c}$ & $4.12 b$ & $5.24 \mathrm{~b}$ & $77.25 \mathrm{e}$ & $84.97 \mathrm{e}$ \\
\hline \multirow{6}{*}{$14 \mathrm{~kg} \mathrm{P}$} & $1 \% \mathrm{~K}$ & $20.39 \mathrm{i}$ & $22.47 \mathrm{e}$ & $2.67 f$ & $2.27 \mathrm{e}$ & $31.19 f$ & $30.06 \mathrm{de}$ & $2.88 \mathrm{ef}$ & $3.58 \mathrm{fg}$ & $89.49 \mathrm{c}$ & $98.44 \mathrm{c}$ \\
\hline & Control & $27.29 b$ & $27.29 \mathrm{bcd}$ & $4.00 \mathrm{c}$ & $3.07 \mathrm{~cd}$ & $32.49 \mathrm{ef}$ & $28.42 \mathrm{ef}$ & $2.80 \mathrm{ef}$ & $2.87 \mathrm{~h}$ & $49.71 \mathrm{i}$ & $54.68 \mathrm{i}$ \\
\hline & $0.3 \% \mathrm{Ca}$ & $24.14 \mathrm{fg}$ & $26.65 \mathrm{bcd}$ & $3.28 \mathrm{e}$ & $2.79 \mathrm{~d}$ & $35.23 \mathrm{~d}$ & $34.03 c$ & $2.68 \mathrm{fg}$ & $3.38 \mathrm{~g}$ & $76.49 \mathrm{e}$ & $84.14 \mathrm{e}$ \\
\hline & $0.6 \% \mathrm{Ca}$ & $22.79 \mathrm{~h}$ & $25.17 d$ & $1.78 \mathrm{i}$ & $1.51 \mathrm{~h}$ & $29.38 \mathrm{gh}$ & $28.39 \mathrm{ef}$ & $3.67 \mathrm{~cd}$ & $4.36 \mathrm{cde}$ & $73.14 \mathrm{f}$ & $80.45 f$ \\
\hline & $0.5 \% \mathrm{~K}$ & $24.42 \mathrm{ef}$ & $26.80 \mathrm{bcd}$ & $6.05 \mathrm{a}$ & $5.11 \mathrm{a}$ & 34.14 de & $32.78 \mathrm{~cd}$ & $2.04 \mathrm{~h}$ & $2.71 \mathrm{~h}$ & $52.88 \mathrm{~h}$ & $58.17 \mathrm{~h}$ \\
\hline & $1 \% \mathrm{~K}$ & $25.99 \mathrm{c}$ & $28.66 b$ & $3.31 \mathrm{e}$ & $2.81 \mathrm{~cd}$ & $44.73 a$ & $43.14 \mathrm{a}$ & $3.41 \mathrm{~d}$ & $4.29 \mathrm{de}$ & $50.33 \mathrm{i}$ & $55.37 \mathrm{i}$ \\
\hline \multirow{5}{*}{$28 \mathrm{~kg} \mathrm{P}$} & Control & $25.04 \mathrm{de}$ & $27.67 b c$ & $2.05 \mathrm{gh}$ & $1.75 \mathrm{gh}$ & $29.32 \mathrm{~h}$ & $28.36 \mathrm{ef}$ & $3.84 \mathrm{bc}$ & $4.49 \mathrm{~cd}$ & $67.67 \mathrm{~g}$ & $74.44 \mathrm{~g}$ \\
\hline & $0.3 \% \mathrm{Ca}$ & $23.33 \mathrm{gh}$ & $25.64 \mathrm{~cd}$ & $3.7 \mathrm{~d}$ & $3.12 \mathrm{c}$ & $30.99 \mathrm{fg}$ & $30.26 \mathrm{de}$ & $3.46 \mathrm{~g}$ & $2.81 \mathrm{~h}$ & $81.87 \mathrm{~d}$ & $90.06 \mathrm{~d}$ \\
\hline & $0.6 \% \mathrm{Ca}$ & $23.34 \mathrm{gh}$ & $25.70 \mathrm{~cd}$ & $2.57 \mathrm{f}$ & $2.18 \mathrm{ef}$ & $27.56 \mathrm{i}$ & $26.56 \mathrm{fg}$ & $3.88 b c$ & $4.59 \mathrm{c}$ & $75.74 \mathrm{e}$ & $83.31 \mathrm{e}$ \\
\hline & $0.5 \% \mathrm{~K}$ & $35.83 \mathrm{a}$ & $39.50 \mathrm{a}$ & $2.48 \mathrm{f}$ & $2.10 \mathrm{ed}$ & $42.1 \mathrm{~b}$ & $40.62 \mathrm{a}$ & $4.63 a$ & $5.75 a$ & $72.12 \mathrm{f}$ & $79.34 \mathrm{f}$ \\
\hline & $1 \% \mathrm{~K}$ & $25.91 \mathrm{c}$ & $28.53 b$ & $4.47 \mathrm{~b}$ & $3.79 \mathrm{~b}$ & $38.49 \mathrm{c}$ & $37.09 \mathrm{~b}$ & $3.7 \mathrm{~cd}$ & $4.15 \mathrm{e}$ & $77.08 \mathrm{e}$ & $73.78 \mathrm{~g}$ \\
\hline \multicolumn{2}{|c|}{ LSD at $5 \%$} & 0.84 & 2.37 & 0.23 & 0.33 & 1.66 & 2.87 & 0.30 & 0.27 & 2.01 & $2.22^{\circ}$ \\
\hline
\end{tabular}

Egypt. J. Soil Sci., 58, No.1 (2018) 
Potassium uptake by tomato fruits significantly increased with increasing phosphorus rate and increased also with the foliar application treatments compared with unfertilized plants. The foliar application treatments of 0.3 and $0.6 \%$ calcium and 0.5 and $1 \%$ potassium increased potassium uptake by $7.61,1.42,31.89$ and $35.85 \%$ in the first season and by $12.39,5.11,36.77$ and $40.28 \%$ in the second season, respectively compared with the control treatment. These results may be attributed to the increment in the yield by the used treatments. The same trend was found with the interaction between phosphorus and foliar treatments where, potassium uptake by tomatoe fruits increased with foliar application treatment under different phosphorus treatments compared with the control treatment except with the treatments of $0.6 \%$ calcium with 14 and 28 $\mathrm{kg} \mathrm{P}$ fed $^{-1}$. The highest potassium uptake values were found with the treatment of $14 \mathrm{~kg} \mathrm{P}^{\mathrm{P}} \mathrm{fed}^{-1}$ and $1 \%$ potassium in both seasons. These results agree with Shafeek et al. (2013) who found that $\mathrm{N}, \mathrm{P} \mathrm{K}$ and $\mathrm{Ca}$ uptake content recorded by foliar application of higher concentration of potassium nitrate emphasizes the role of $\mathrm{K}$ in plant metabolism and its involvement in many associated processes (Marschner,1995).

Concerning calcium uptake by tomato fruits $\left(\mathrm{kg} \mathrm{fed}^{-1}\right)$, the present data illustrate that calcium uptake by tomato fruits is significantly affected by phosphorus treatments, foliar application treatments and their interaction. It increased by increasing phosphorus rate and foliar treatments. These results may be due to increasing yield with increasing phosphorus rates. In addition, it was observed that at the lower phosphorus rate $(0 \mathrm{~kg}$ $\left.\mathrm{fed}^{-1}\right)$, foliar treatments increased calcium uptake by tomato fruits $\left(\mathrm{kg} \mathrm{fed}^{-1}\right)$ compared with the other phosphorus treatments. The highest values calcium uptake by tomatoe fruits $\left(\mathrm{kg} \mathrm{fed}^{-1}\right)$ were

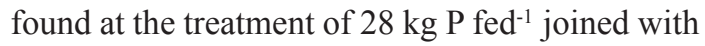
$0.5 \%$ potassium as a foliar application in both seasons.

\section{Fruit lycopene content $\left(\mathrm{mg} \mathrm{kg}^{-1}\right)$}

Data in Table 5 show that the different treatments significantly affected fruit lycopene content where it decreased with increasing phosphorus rates compared with the control. These results may be due to the low volume of tomatoe plant in this treatment and the effect of climate factor (solar radiation and temperature). These results agree with Oke et al. (2005) who observed that climatic factors had more effect than $\mathrm{P}$ fertilization on the lycopene content of tomatoes. While, lycopene content was increased with foliar application treatments especially calcium treatments. This result may be associated with the little content of calcium in the studied soil. These results are in contrast with that of Paiva et al. (1998) and in agreement with that of Kazemi, (2014) who found that potassium nitrate increased fruit lycopene content. The highest fruit lycopene content $\left(\mathrm{mg} \mathrm{kg}^{-1}\right)$ values $\left(84.55\right.$ and $\left.93 \mathrm{mg} \mathrm{kg}^{-1}\right)$ were recorded with the treatment of $0.3 \%$ calcium in both seasons. The same trend was found with the interaction between phosphorus treatment and foliar application treatments. The obtained data also illustrate that at $0 \mathrm{P} \mathrm{kg} \mathrm{fed}^{-1}$ combined with calcium treatments, lycopene content was higher than potassium treatment compared with the control treatment. Also, lycopene content decreased with the integration between $14 \mathrm{~kg}$ $\mathrm{P} \mathrm{fed}^{-1}$ and foliar treatments than the control. These results may due to the effect of phosphorus increment rate, soil calcium content and nutrient balance which affected photosynthesis, pigments and also the negative correlation with phosphorus content $(\mathrm{r}=-0.54$ and $-0.52, P<0.05$ level $)$ in both seasons, respectively. The treatment of 0 phosphorus rate and $0.3 \%$ calcium recorded the highest fruit Lycopene content $\left(\mathrm{mg} \mathrm{kg}^{-1}\right)$ values (95.29 and $104.81 \mathrm{mg} \mathrm{kg}^{-1}$ ) followed by 0 phosphorus rate and $0.6 \%$ calcium in both seasons, respectively. These results may be due to reduced yield in these treatments compared with the other treatments.

\section{Conclusion}

Finally, phosphorus treatments, foliar treatments and their interaction significantly influenced tomato growth, yield and nutrient uptake. Lycopene content significantly increased with foliar application treatments especially calcium treatments. Generally, we concluded that the interaction between the treatment of $14 \mathrm{~kg} \mathrm{P}$ fed $^{-1}$ and $0.3 \%$ calcium or $0.5 \%$ potassium as a foliar application enhanced and increased tomato growth, yield and nutrient uptake.

\section{Referances}

Adamec, L. (2002) Leaf absorption of mineral nutrients in carnivorous plants stimulates root nutrient uptake. New Phyt. 155 (1), 89-100

Afzal, I., B. Hussain and S. M. A. Basra1 (2015) Foliar application of potassium improves fruit quality and yield of tomato plants. Acta Sci. Pol., Hortorum Cultus, 14(1), 2015, 3-13.

Egypt. J. Soil Sci., 58, No.1 (2018) 
Akhtar, M. E., Khan,M. Z. , Rashis, M. T., Ahsan, Z. and Ahmad, S. (2010) Effect of potash application on yield and quality of tomato (Lycopersiconesculentum Mill.). Pak J. Bot. 42, 1695-1702.

Anac, D., Eryuce, N. and Kilinc, R. (1994) Effect of N, $\mathrm{P}, \mathrm{K}$ fertilizer levels on yield and quality properties of processing tomatoes in Turkey. Acta. Hort., 376, 243-250.

AOAC International (2012) Official Methods of Analysis of AOAC International. 19th edition. 2nd revision. Gaithersburg, MD, USA, Association of Analytical Communities.

Bidari, B.I. and Hebsur, N.S. (2011) Potassium in relation to yield and quality of selected vegetable crops. Karnataka J. Agric. Sci., 24 (1), 55-59.

Black, C.A. (1965) Methods of Soil Analysis. Part I, American Society of Agronomy. Madison, Wisconsin, USA.

Carter, M.R. and Gregorich,E.G. (2007) "Soil Sampling and Methods of Analysis". Second edition, Canadian Society of Soil Science.

Chapman, H.D. and Pratt, P.F. (1978) Methods of Analysis for Soils, Plants and Waters. Univ. California Div. Agric. Sci. Priced Publication, Oakland.

Cottenie, A. M. VerIoo, Kiekens, L., VeIgh, G. and Camerlynck,R. (1982) "Chemical Analysis of Plants and Soils" State Univ. Ghent Belgium, 63.

Davis, J.M., Sanders, D.C., Nelson, P.V., Lengnick, L. and Sperry, W.J. (2003) Boron improves the growth, yield, quality and nutrient content of tomato. Journal American Society Horticulture Science, 128, 441-446.

Dhinakara, R. and Savithri, P. (1997) Phosphorus use efficiency of tomato asinfluenced by phosphorus and vesicular aurbuscularmycorrhizal (VAM) fungi inoculation. J. Nuclear Agric. Biol., 26 (3) 142-146.

Groot, C.C. (2002) Phosphorus and nitrogen nutrition in tomato - a physiologicalanalysis of plant growth. Ph D thesis, Utrecht University, the Netherlands.

Morard, P., Pujos, A., Bernadac, A. and Bertoni,G. (1996) Effect of temporary calcium deficiency on tomato growth and mineral composition. J. Plant Nutr. 19, 115-127.

Haluschak, P. (2006) Laboratory methods of soil analysis. Canada Manitoba soil survey p.12.

Hao, X. and Papadopoulos,A.P. (2003) Effects of calcium and magnesiumon growth, fruit yield and quality in a fall greenhouse tomato crop grown onrockwool. Can. J. Plant Sci. 83, 903-912.

Egypt. J. Soil Sci., 58, No.1 (2018)
Usten, N.H., Yokas, A.L. and Saygili , H. (2006) Influence of potassium and calcium level on severity of tomato pith necrosis and yield of greenhouse tomatoes. ISHS ActaHortic 808, 345-350.

Hesse, P. R. (1971) “A Text Book of Soil Chemical Analysis" ToonMurry (publishers) Ltd, 50 Albemarle Street, London. p. 299.

Idowu, G.A., Oyewale, R.O., Yusuf, S.T., Isah, A. S. and Bello,L. Y. (2013) Effect of phosphorus application on growth, yield and yield components of snake tomato (Trichosanth escucumerina L.) World Journal of Agricultural Sciences , 1 (3), pp. 088-093.

Ilyas, M., Ayub,G. , Hussain, Z., Ahmad,M., Bibi,B. , Rashid, A. and Luqman (2014) Response of Tomato to Different Levels of Calcium and Magnesium Concentration. World Applied Sciences Journal. ISSN 1818-4952, 31 (9), 1560-1564.

Jones, J.B. (1999) Tomato plant culture: in the field green house and home garden.CRS Press, LLC. Florida, pp: 11-53.

Kadir, S.A. (2004) Fruit quality at harvest of 'Jonathan' apple treated with foliar applied calcium chloride. J. Plant Nut. 27, 1991-2006.

Kanai S., Moghaieb,R. E., El-Shemy,H. A.,. Panigrahi, R., Mohapatra, P. K., Ito,J. , Nguyen, N.T., Saneoka,H. and Fujita, K. (2011) Potassium deficiency affects water status and photosynthetic rate of the vegetative sink in green house tomato prior to its effects on source activity. Plant Sci. 180, 368-374.

Kanai, S., Ohkura, K., Adu-Gyamfi,J.J., Mohapatra, P.K., Nguyen, N.T., Saneoka, H. and Fujita, K. (2007) Depression of sink activity precedes the inhibition of biomass production in tomato plants subjected to potassium deficiency stress. Journal of Experimental Botany, 58, No. 11, pp. 2917-2928.

Kazemi, M. (2014) Effect of Gibberellic Acid and Potassium Nitrate Spray onVegetative Growth and Reproductive Characteristics of Tomato. J. Biol. Environ. Sci., 2, 8 (22), 1-9.

Marschner, H. (1995) Mineral Nutrition of Higher Plants. Springer, New York.

Mishra, D.N. and Singh, L.R. (2006) Effect of N, P fertilization on the performance and production economics of rainfed okra intercropped with tomato under mid-hill condition of uttranchal. Environ. \& Ecol. 546-550.

Oke, M., Ahn, T., Schofield, A. and Paliyath, G. (2005) Effects of phosphorus fertilizer supplementation on processing quality and functional food ingredients in tomato. Journal of Agricultural and Food 
Chemistry, 53, 1531-153.

Paiva, E.A.S., Sampaio,R.A. and Martinez, H.E.P. (1998) Composition and quality of tomatofruit cultivated in nutrient solution containing different calciumconcentrations. J. Plant Nutr. 21, 26532661.

Pandey,. P., Solanki,P. N., Saraf, R. K. and Parihar,M. S. (1996) Effect ofnitrogen and phosphorus on growth and yield of tomato (Lycopersicon esculentum Mill.) varieties. Punjab Veg. Grow., 32, 1-5.

Peyvast. G., Olfati, J. A., Ramezani-Kharazi,P. and Kamari-Shahmaleki, S. (2009) Uptake of calcium nitrate and potassium phosphate from foliar fertilization by tomato. J. Horticulture and Forestry, 1(1) pp. 007-013.

Ravelo-Pérez, L.M.,Hernández-Borges, J., RodríguezDelgado, M. A. and Borges-Miquel, T. (2008) Spectrophotometric Analysis of Lycopene in Tomatoes and Watermelons: A Practical Class. The Chemical Educator, Vol. 13, No. 1.

Rending,V.V. and Taylor, H.M. (1989) Principles of Soil-plant interrelationships. McGraw-Hill. 100$101 ; 185-186$.

Shafeek, M.R., Helmy, Y.I., El-Tohamy, W.A. and El-Abagy, H.M. (2013) Changes in growth, yield and fruit quality of cucumber (Cucumissativus L.) in response to foliar application of calcium and potassium nitrate under plastic house conditions. Research Journal of Agriculture and Biological Sciences, ISSN 1816-1561, 9 (3), 114-118.
Sharma, N. K., Raman. J. Singh, and Kumar, K. (2012) Dry matter accumulation and nutrient uptake by wheat (Triticum aestivum L.) under poplar (Populusdeltoides) based agroforestry system. ISRN Agronomy. Vo1. 2012. ID 359673.

Sun, Z., Shengli, L. and YanLing,Z. (2004)Relationship between $\mathrm{N}, \mathrm{P}$ and $\mathrm{K}$ application and the growth of tomato seedlings sown in sawdust enriched substrates. J. South China Agril. Univ., 25 (1), $25-$ 28.

Taylor, M.D. and Locascio, S.J. (2004) Blossom-End Rot: A CalciumDeficiency. J. Plant Nutr. 27, 123139.

Van Reeuwijk, L.P. (2002) 'Procedures for Soil Analysis' (International Soil Reference and Information Centre (ISRIC): Wageningen

Véry, A. A. and Sentenac, H. (2003) Molecular mechanisms and regulation of $\mathrm{K}+$ transport in higher plants. Annu. Rev. Plant Physiol. Plant Mol. Biol. 54, 575-603.

Zhang, T.Q., Tan, C.S. and Liu, K. (2009) Phosphorus and potassium application to processing tomatoes grown with drip irrigation. Acta Horticulturae. 823, 97-102.

Zhao, D., D.M. Oosterhuis and C.W. Bednarz (2001) Influence of potassium deficiency on photosynthesis, chlorophyll content, and chloroplast ultra-structure of cotton plants. Photosynthetica 39, 103-109.

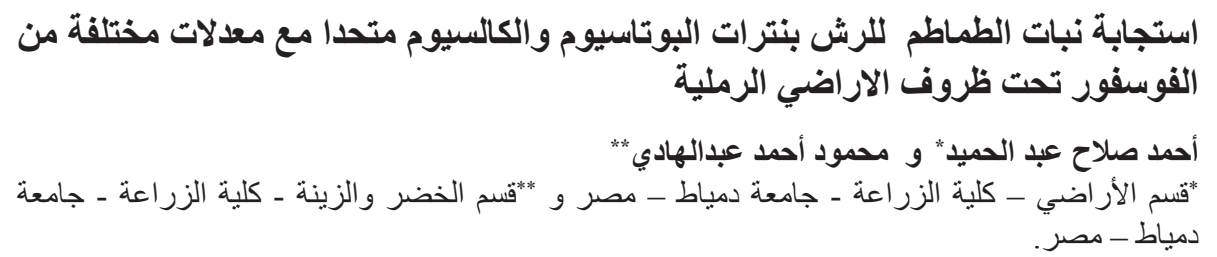

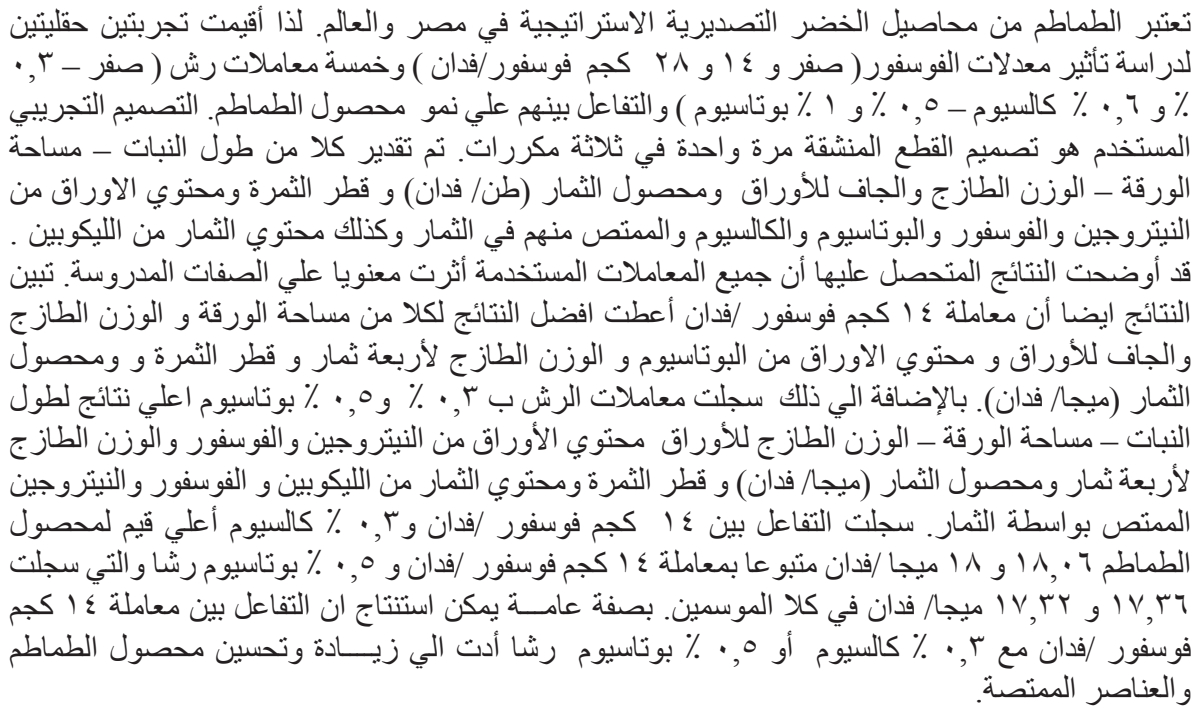

Egypt. J. Soil Sci., 58, No.1 (2018) 